\title{
Consumers' Awareness on Their Basic Rights and Willingness to Pay for Organic Vegetables in Ethiopia
}

\author{
Belay T. Mengistie ${ }^{*}$ \\ Addis Ababa University, Ethiopia \\ (Received February 20, 2020; Accepted April 2, 2020; Published April 22, 2020)
}

\begin{abstract}
In developing countries, widely reported incidents of dangerous levels of pesticides in food have stimulated the demand for organic food, a movement to choose organic agriculture. It also makes more people have desires to consume chemical free foods. This study, therefore, assessed the consumers' awareness of their eight basic rights and willingness to pay for organic vegetables in Ethiopia. The data were collected from 200 respondents (consumers) from Addis Ababa and 80 smallholder vegetable farmers at Ziway and Meki through a combination of random and purposive sampling procedures using a structured interview and were analyzed using descriptive analysis. The results show that vegetable producers used a lot of chemicals, but not in a safe way or at the optimum level. The findings also show that the overall degree of consumers' awareness on the eight consumer rights is low. Furthermore, willingness to pay premium prices about $5-50 \%$ to obtain organic products, which can be viewed as the cost of investment in human health, is encouraging. There is a need to target agricultural policies relating to handling practices and for public health policies to be more differentiated in promoting food safety. Informing consumers about unique characteristics of organic production methods, the strict inspection and required third party certification might be a promising strategy to develop the market for organic vegetables in Ethiopian urban centers.
\end{abstract}

Keywords: certification, consumers'awareness, Ethiopia, labeling, rights, willingness to pay

JEL Classification: D18, Q10, Q18

\section{INTRODUCTION}

Vegetable production in Ethiopia is now significantly dependent on pesticides, either on large scale production or smallholder production systems (Damte \& Tabor, 2015; Mengistie, Mol, \& Oosterveer, 2016, 2017a, 2017b; Mengistie, Mol, Oosterveer, \& Simane, 2015; Negatu, Kromhout, Mekonnen, \& Vermeulen, 2016). Inappropriate application of pesticides can damage the farmland environment (Pimentel, 1995), and it imposes on the health of the farmer and the people consuming crops and vegetables (Amoabeng, Gurr, Gitau, \& Stevenson, 2014; Amoah, Drechsel, Abaidoo, \& Ntow, 2006; Bhattarai, 2019; de Bon et al., 2014; Lund, Sthre, Nyborg, Coulibaly, \& Rahman, 2010;

\footnotetext{
* Corresponding author email: belaytizazu@yahoo.com, ISSN 2615-6075 online; ISSN 2615-6946 print @UWG Press, 2020

OJS http://publishing-widyagama.ac.id/ejournalv2/index.php/jsed/
}

Martin, Assogba-Komlan, Houndete, Hougard, \& Chandre, 2009; Ntow, Gijzen, Kelderman, \& Drechsel, 2006; Timbilla \& Nyarko, 2004; Williamson, 2012). Nearly $75 \%$ of the 200 thousand deaths associated with pesticide poisoning occur in developing countries even though they use only $15 \%$ of global pesticide supply (Armah, 2011; Darko \& Akoto, 2008). The extensive use of chemicals in vegetable production has been a major source of health risk (Hough, 2003) as well as a cause of environmental pollution. Food safety should be a major concern of many vegetable farmers at pre and post-harvest stages in which farmers and consumers also face threats related to health as well as contaminating the environment (Eom, 1994).

The position of organic agriculture in providing food and income is now gaining extensive acknowledgment (Dipeolu, Philip, Aiyelaagbe, 
Akinbode, \& Adedokun, 2009). The market for organic products is growing as the number of people willing to consume organic food and pay the premium price. The prospect of organic agriculture will also depend on the consumer demand and the customers' reason for spending the extra price for organically grown food. A consumer-oriented approach to address the market of organic products is important for employing better organic farming management. However, this process is determined by factors such as quality production, infrastructure, market environment, certification, and policies (Aryal, Chaudhary, Pandit, \& Sharma, 2009).

Environmental awareness and consumer awareness of healthy and safe food have called attention in the last three decades in developed countries, leading to a significant increase in safe organic product demand (Batte, Hooker, Haab, \& Beaverson, 2007; Gil, Gracia, \& Sánchez, 2000; Loureiro, Mccluskey, \& Mittelhammer, 2002; Van Loo, Caputo, Nayga, Meullenet, \& Ricke, 2011; Zander \& Hamm, 2010). In similar, it has received considerable research attention in Asia (Bhattarai, 2019; Vanit-Anunchai \& Schmidt, 2004; Zander \& Hamm, 2010). Conversely, it has not much occurred in African countries, with few case studies from either consumer or producer perspectives (Amoabeng et al., 2014). The consumer preference studies in African countries typically relate to biofortified foods (De Groote \& Kimenju, 2008).

Recent studies carried out in Ethiopia (Jansen \& Harmsen, 2009; Mengistie et al., 2016, 2017a; Negatu et al., 2016) have shown that a wide range of pesticides use is in containers ranging from 0.25 to $5 \mathrm{I}$ (sometimes even $200 \mathrm{I}$ ), or in packets ranging from 0.5 to $25 \mathrm{~kg}$. Farmers using pesticides are, however, not adequately informed about their hazards. Pesticide usage is often accompanied by misuse leading to acute poisoning and health issues such as headaches, vomiting, skin irritation, and eye irritation.

Awareness about the negative effects of the use of synthetic chemical fertilizers and pesticides is gaining momentum around the world, opting for organically produced food products. Information about consumers' awareness of basic rights is an essential element for farmers and marketing agencies to successfully plan production that can capture a greater market share. This study discusses effective factors influencing consumers' awareness about the benefits of organic vegetable production in Ethiopia.

Governance (management) failures in Ethiopia (Mengistie et al., 2016; Negatu et al., 2016) are the origin of many environmental and human health problems regarding pesticides. Importantly, nobody has studied consumers' attitudes toward vegetable production and consumption. This paper describes that influencing and understanding consumer behavior will help design market incentives for farmers, which enables sustainable and economically viable production of safe vegetables using IPM work. This research can reveal the tradeoff between paying a higher price and consuming less or pesticide-free vegetables using IPM technology instead of vegetables with high pesticide residues. Besides having the potential to provide information to decision-makers about promoting IPM technology, this study also contributes to the growing literature on consumer preferences for high quality and safe fresh food products in developing countries.

The main objective of this study is to assess on consumers' awareness on their basic rights and willingness to pay the organic vegetable products as a pesticide governance mechanism in Ethiopia. The work of the study is (i) to assess understanding of consumers' awareness towards organic products and pesticide residue; (ii) to identify factors influencing consumers' willingness to pay (WTP) the organic products, the tendency of their consumption, and implications on organic vegetable labeling and certification.

\section{RESEARCH METHOD}

The respondents of the study composed of consumers from four selected supermarkets (namely, Safe way, Almart, Fresh corner, and Shewa) in Addis Ababa City. The researchers utilized purposive sampling in the selection of supermarket with over 1,500 customer-volumes per day. Respondents were selected based on their willingness to answer the survey.

This survey was conducted on a sample survey of 200 respondents (vegetable consumers) from Addis Ababa and 80 farmers (growers) from Ziway 
and Meki between 1st March and 30 April 2019). Addis Ababa is Ethiopia's largest city and it serves as the economic capital, hosting the biggest business centers and almost all public services and which also consists of low, middle and high-income consumers of vegetables. Ziway, and Meki districts have a large number of pesticides' retailers and are important vegetable-producing areas in Ethiopia. Information about pesticide use practices includes the types of pesticides used, how pesticides are selected, factors that influence the pesticide selection and the usage, ability to read the information available on the label and technical training. Responses were tabulated and weighted.

The questionnaire was adopted from the survey instrument used by previous researchers. The questions were structured using 5 point Likert type scales or range of values (high $=4.2-5.00$ ), (moderate $=3.41-4.20), \quad($ low $=2.61-3.40), \quad$ (very low=1.81-2.60), and (poor=1.00-1.80). A Likert scale provides a great way of measuring attitudes, knowledge, perceptions, values, and behavioral changes. A Likert-type scale involves a series of statement that survey respondents may choose, in order to rate their responses of evaluative questions. The researchers involved enumerators in surveying during May and August 2019. The respondents were 18 years old and above.

A combination of purposive and random sampling technique was applied. The data were collected through a well-structured questionnaire containing questions on awareness about organic food and socioeconomic and demographic information of the respondents. The questionnaire for this study was designed to ask the respondents about their level of awareness about basic consumer rights, organic vegetable products, organic vegetable market characteristics, and the ranking for the importance of organic vegetable features, such as their perception of whether they consider the organic vegetable product to be chemical-free, fresh and healthy, better-tasting or not. For example, a question from the questionnaire asks the customers whether or not they purchase organic vegetables considering the benefits they get, when the price is expensive. The question enables the researcher to conclude the correlations between such explanatory variables on one side and the research-dependent variable, namely awareness about organic vegetable (chemical-free) (Muhammad, Fathelrahman, \& Ullah, 2017).

The right pertains to safety makes sure that consumers are protected against the marketing of goods, which are harmful to health and life. Consumers are assured that producer of consumer products undertake extensive safety and performance testing before selling their products in the market. Products should be appropriately labeled with information as to the contents, use, precautions or warning signs and how to prepare it if the need arises. Consumer awareness refers to product characteristics, exploration, and recognition by consumers. This is the organic product's characteristic/attribute such as chemical-free, nutritional content, whether the product is certified organic or not, locally produced or imported, country of origin (if it is imported), labeling information including date of expiration, and level of freshness. Furthermore, specific brands are likely to be considered by the consumers to have high quality organic products, so such consideration may affect his or her decision-making about purchasing a specific brand of food products (Al-Taie, Rahal, AL-Sudani, \& AL-Farsi, 2015).

\section{RESULT AND DISCUSSION}

\section{Socioeconomic and Demographic Characteristics}

It is essential to give the background about the demographics of the survey respondents before examining in-depth their responses. The profile of organic consumers who influence awareness and willingness-to-pay for organic products is summarized in Table 1.

The table shows the demographic characteristics of the respondents. The majority of respondents (54\%) were male, whereas $46 \%$ were female. The table state that majority $(36 \%)$ of the respondents belong to the age between 36 and 45 years, while $24 \%$ in the age from 29 to 35 years, $19 \%$ of them in between 46 and 55 years, $11 \%$ in the age between 56 and 65 years, six percent above 65 years and the remaining four percent below 19 years. It is evident that most $(58 \%)$ of the respondents are married, and $42 \%$ of the respondents are unmarried. 
The distribution of respondents by education level shows that $26 \%$ of respondents have first degree (BSc/MA) level of education, $43 \%$ have the second degree (MSc/MA) and those with third degree $(\mathrm{PhD})$ and above the level of education are $31 \%$. It is understood that most $(60.28 \%)$ of the respondents are qualified with post-graduation.

Table 1. Profile of The Respondent (Consumers)

\begin{tabular}{|c|c|c|}
\hline Variables & Response & Percentage \\
\hline \multirow[t]{2}{*}{ Gender } & Male & 54 \\
\hline & Female & 46 \\
\hline \multirow[t]{6}{*}{ Age } & $19-28$ & 4 \\
\hline & 29-35 & 24 \\
\hline & $36-45$ & 36 \\
\hline & $46-55$ & 19 \\
\hline & $56-65$ & 11 \\
\hline & $65+$ & 6 \\
\hline \multirow[t]{2}{*}{ Marital status } & Married & 58 \\
\hline & Unmarried & 42 \\
\hline \multirow[t]{3}{*}{ Education level } & $\mathrm{BSc} / \mathrm{BA}$ & 26 \\
\hline & $\mathrm{MSc} / \mathrm{MA}$ & 43 \\
\hline & $\mathrm{PhD}+$ & 31 \\
\hline Income (thousand ETB, Ethiopian Birr) (1 USD = & Up to 5 & 8 \\
\hline \multirow[t]{5}{*}{$32.5430 \mathrm{ETB})$} & $5-10$ & 17 \\
\hline & $10-15$ & 13 \\
\hline & $15-20$ & 35 \\
\hline & $20-25$ & 24 \\
\hline & $25+$ & 5 \\
\hline \multirow[t]{3}{*}{ Category of work place } & Governmental & 37 \\
\hline & NGOs & 30 \\
\hline & Private companies & 33 \\
\hline \multirow[t]{4}{*}{ Frequency of Purchase vegetable } & Daily & 3 \\
\hline & Weekly & 52 \\
\hline & Every two weeks & 36 \\
\hline & Every three weeks & 9 \\
\hline \multirow[t]{3}{*}{ Source of your vegetable } & Local retailers & 51 \\
\hline & Supermarkets & 35 \\
\hline & Farms(producer) & 14 \\
\hline \multirow[t]{3}{*}{ Awareness of organic vegetables } & Highly aware & 78 \\
\hline & Moderately aware & 19 \\
\hline & Not aware & 3 \\
\hline \multirow{3}{*}{$\begin{array}{l}\text { Awareness about the impact non-organic nature } \\
\text { of the food products(i.e vegetables) }\end{array}$} & Highly aware & 23 \\
\hline & Moderately aware & 62 \\
\hline & Not aware & 5 \\
\hline \multirow[t]{3}{*}{ Awareness of pesticide residue in/on vegetables } & Highly aware & 6 \\
\hline & Moderately aware & 11 \\
\hline & Not aware & 83 \\
\hline \multirow{2}{*}{$\begin{array}{l}\text { Awareness of organic food standards } \\
\text { (certification and labeling) }\end{array}$} & Aware & 13 \\
\hline & Not ware & 87 \\
\hline Willingness to pay a premium for organic & Yes & 74 \\
\hline vegetables & No & 26 \\
\hline
\end{tabular}

Sample size: 200 respondents

The distribution of respondents by monthly income group, i.e., up to five thousand ETB accounted eight percent, 5 - 10 thousand ETB accounted seven percent, $10-15$ thousand ETB accounted 13\%, 15 - 20 thousand ETB accounted $35 \%, 20-25$ thousand ETB accounted 24\% and above 25 thousand ETB accounted five percent of the total respondents. Most of the respondents
(51\%) purchased vegetable products from the local retailers, 35\% respondents bought them in supermarkets, and $14 \%$ respondents directly purchased them from the farmers/grower/producers. The purchase behavior of the consumers was assessed based on the frequency of purchase and most (52\%) of respondents purchased vegetables weekly. On the 
other hand, some of the respondents (36\%) liked to buy vegetables twice a week.

\section{Pesticide Use Practices among Farmers}

Farmers in developing countries face a variety of problems and constraints. In Ethiopia, insect pests are one of the major constraints for vegetable production. Pesticides have been used in response to these losses and played major roles in increasing agricultural production. Although farmers kept no records of the number of pesticides sprayed, they explained that their spraying frequency varied, depending on climatic conditions (rainy and dry season) and crops. During rainy seasons, when pests and diseases proliferate, the farmers sprayed more. Then most farmers applied the increased dosages as from experience; the recommended amount proved ineffective; they used the term mooq ( $a$ bit higher than the dose). When the pests were not sufficiently reduced after pesticide application, the farmers increased the concentration, the frequency and/or change the types of pesticides without any instruction. Some tomato farmers mixed insecticides and fungicides and sprayed as many as 17 times in a wet season and eight times in a dry season, while a maximum of five was recommended when the worst infestation occurs. The longer growing season of crops like tomato entailed a higher frequency of sprays per season. No farmer followed the recommended spraying intervals.

In the research, 41 different types of commercial pesticides were used by the farmer. It contained chemical compounds such as organophosphates, organochlorines, pyrethroids, and carbamates. Organophosphates and pyrethroids are categorized as high toxicity (WHO class II, moderately hazardous), were applied at different growing stages. In vegetable farming, insecticides (58\%) were the most used pesticides because of severe insect pests in Central Rift valley. This was followed by fungicides ( $42 \%$ ) usage.

Generally, this paper confirmed that those farmers applied pesticides in violation of the recommendations. In essence, they used unsafe storage facilities, ignored risks and safety instructions, and did not use protective devices when applying pesticides and disposing containers unsafely.

\section{Consumer Awareness}

Consumers' awareness and concern have been shown to influence and predict behavior. This survey assessed the diverse consumer awareness of organic vegetables and pesticide residue. The diversity among consumers is based on a variety of factors, including demographics and socioeconomic characteristics. Furthermore, to understand the consumers' views concerning different issues, there was a discussion in detail on the issues with the respondents.

The analysis of data shows that $96 \%$ of the total of 200 respondents were aware of the term organic vegetables, and the remaining $4 \%$ were unaware of organic vegetables. A majority of respondents defined the term related "organic" to ideas of freshness, being natural, healthy, and the absence of pesticides. While $73 \%$ of the respondents responded that it was food not sprayed with pesticides; $68 \%$ stated that it was food grown using manure and without chemical fertilizer. $43 \%$ mentioned that the vegetables were environment friendly, $58 \%$ said that they did not have chemicals, $14 \%$ perceived them as healthy, and $23 \%$ said that they were natural. If they asked to choose between conventional and organic vegetable products, $83 \%$ preferred organic foods, while seven percent remaining said that they did not know any difference to them. Interestingly, although a large majority of the respondents were familiar with organic vegetables, they did not know where to buy organic foods. The main reasons for this answer were lack of supply (67\%), and the origin of the product was not trustworthy (54\%).

This survey found that a majority of the surveyed consumers had known about organic products. However, they were often not sure which products were organic. This finding is in line with (Bhatta, Doppler, \& Bahadur, 2009), who report that about $92 \%$ of the consumers knew about organic agriculture.

It is understood that most (62\%) of the respondents were moderately aware about the impact non-organic nature of the food products, while $23 \%$ of the respondents were highly aware and the remaining five percent of the respondents were not aware about the impact of non-organic products. It is observed that more than half $(68 \%)$ 
consumers believed that the presence of pesticide residues was highly unsafe for health, and the remaining $32 \%$ of the respondents were not aware about the same.

Pesticide use and pesticide residues in foods, including vegetables and fruits, have been the subject of controversial public discussion and media coverage in developed countries. Against this background, as assessed with the closed-ended question, levels of concern about maximum pesticide residues level were low for vegetables. It is clear from the above table that most (83\%) of the respondents were not aware about the pesticides present in the non-organic vegetable products, compared to $11 \%$ of the respondents who were moderately aware, and only $6 \%$ of the respondents were highly aware. The main barrier to increasing the market share of organic vegetables is that consumers did not clearly differentiate between the various 'pesticide safe' labels and organic labels.

The relationship between consumer demographics and socioeconomic characteristics regarding food safety (vegetables vs. pesticide) is also examined in this paper. Age was also a significant independent variable. For respondents 36 years of age and older, $78 \%$ of them were very concerned about chemical pesticides in vegetable while $22 \%$ of them were less concerned about chemical pesticides under 36 years of age.

The gender variable shows that male respondents had more awareness about organic vegetables than their female counterparts. The reason behind more organic food awareness among male members was because overall, male members were relatively more educated in developing countries, in which these studies were conducted, and this was linked to the higher literacy level in men compared to women in Ethiopia. Education development creates a rational mind and awareness among consumers.

Illiteracy was one of the impediments in the way of the consumer awareness. It was expected that there would be a positive relationship between education, consumer rights, and protection awareness since the level of awareness was expected to increase as the level of education soared. This is consistent with the findings of
(Babin \& Darden, 1995; Ishak \& Zabil, 2012), who found a significant difference in the level of awareness of consumer rights across consumers with different levels of education. Awareness level increases with the level of education. This means that more educated consumers are aware of their rights. This survey found a significant positive relationship between the level of education and consumer behavior towards organic vegetable and pesticide residue.

With regards to income, it is the main factor that determines purchasing power, consumption levels, and tastes of consumers. A Higher income level corresponds to the higher purchasing power, and vice versa. It was expected that there would be a positive relationship between income and consumer awareness of their rights. Research of (Mason, 2007) on consumer protection awareness in South Africa found that there was a strong positive relationship between consumer incomes and awareness on the four basic consumer rights at the $99 \%$ confidence level. In other words, the higher the income the respondents earned, the more likely they were to know their basic consumer rights. This could be because high-income consumers may be more informed, willing to learn and pay attention to different types of media (including educational programs), which exposed them to this consumer awareness and knowledge. This is supported by (Wilson, 2008) who observes that low-income consumers are not only more likely victims of abuse by lenders, but they are also less aware of consumer protection provisions and their rights to seek recourse. In this survey, $82 \%$ of the respondents who had an annual income of above 15 thousand ETB said that they were aware of the use of organic vegetables.

\section{Consumers' Awareness on The Eight Basic Rights}

Table 2 summarizes the overall degree of consumers' awareness of respondents in the Addis Ababa on their eight basic rights. The overall degree of consumers shows "low" awareness with an average mean score, 3.16. As shown in Table 2, in Addis Ababa the rights of consumer safety, information choice, education and health environment got the low mean score, 2.84, 3.27, $3.23,3.26,3$, and 3.04 , respectively. While the right to representation got the lowest mean of 2.51 and 
the right to basic needs and redress got the moderate level of 3.53 and 3.58, respectively. Although the overall degree of consumer awareness is low, there is a difference in their awareness to indifferent consumer rights.

Table 2. Overall Degree of Consumers' Awareness

\begin{tabular}{|c|c|c|c|}
\hline No & Rights $^{1}$ & Weighted Mean (WM) & Degree of Awareness \\
\hline 1. & The right to basic needs. & 3.53 & Moderate \\
\hline 2. & The right pertains to safety. & 2.84 & Low \\
\hline 3. & The right to information. & 3.27 & Low \\
\hline 5. & The right to representation. & 2.51 & Very Low \\
\hline 6. & The right to redress. & 3.58 & Moderate \\
\hline 7. & The right pertains to consumer education. & 3.26 & Low \\
\hline & Average & 3.16 & Low \\
\hline
\end{tabular}

Sample size: 200 respondents

Description of eight basic rights is presented in the Appendix

\section{Certification and Tendency to Buy An Organic Vegetable}

At present, consumers buy the foods/vegetables relied on their trust with the traders and producers. As such, consumers have put forward their opinion for the certification of the products with the authorized certification body. A majority of the consumers (71\%) stated that they did not trust the product because there is no mechanism that differentiates organic from inorganic. This means that there are no certified products providing good label containing full information. Besides, the researcher never observed labeling on vegetables in the selected supermarkets of Addis Abba such as Safe Way, AlMart, Shewa, and Fresh Corners. Given these factors, consumers were asked: "Do you have a tendency to buy an organic labeled vegetable. Around $63 \%$ respondents were not aware of organic standards/certifications and labels. Some $(37 \%)$ of the respondents were aware about the certified organic products that can be identified by an organic logo and label. It indicates that there is a strong need for creating awareness.

Similarly, consumer preference portrays a general perception that organic products have more desirable characteristics than conventionally grown ones. In the health perspective, consumer preferences generally consider food safety based on product characteristics such as nutritive value, taste, freshness, appearance, color and expiry date, and environmental reasons.

This survey shows that the tendency for organic vegetable consumption is moderate. Knowledge and awareness about organic products can affect attitudes and perceptions about the product and consumers' decisions to buy. After the researcher informed the pesticide effect on human health and environment, $78 \%$ of consumers said that organic certification was important to them. These positive portraits allow governments and producers to invest in organic cultivation and take advantage of a new and promising market. Results also show that "proper appearance" does not have a significant effect on the tendency to purchase organic vegetables. This would be a valuable advantage for organic producers because it enables them to change their farming technology from conventional to organic is very worried about "nonproper vegetables' appearance" in organic cultivation and its effect on their market. As the results showed, almost all of the consumers prefer to purchase an organic vegetable with a governmental certified "organic" label. These results should alert governments and producers to work together in making comprehensive organic vegetable production regulations in Ethiopia. It is proposed that organic vegetable production must be promoted and supported by the government. The governments can increase the tendency for the consumption of organic vegetables by increasing public awareness and governmental rewards and providing subsidy for organic producers.

\section{Consumers' Willingness to Pay for Organic Products}

The majority $(74 \%)$ of the respondent showed willingness to pay a premium (higher prices) for organic vegetables, and the remains, $24 \%$ of them 
were unwillingness to pay a premium. The price premium is ranging from $5-50 \%$ depending upon the products and consumers' willingness to buy. The survey revealed that $36 \%$ of the interviewed consumers were willing to pay up to $20 \%$ premium price compared with the non-organic. Similarly, $13 \%$ of consumers liked to pay between $20-50 \%$ premium price. In comparison, $51 \%$ of consumers were not willing to pay more than $10 \%$ premium price for any organic products.

This higher WTP among consumers in developing countries may be explained by the urge to purchase healthy and safe fresh food, with nonregulated abuse of pesticide use. A similar study in Iran by Asadi, Akbari, Sharifzadeh, \& Hashemi (2009) reported that the majority of the consumers are not willing to pay a premium price higher than $20 \%$. The study by Katrin et al., 2013 in Denmark also reported that $35 \%$ of the consumers were willing to pay more for any type of organic product compared to $18 \%$ of consumers who were not willing to pay for all kinds of products. Menon (2008) argued that the organic product is gaining premium price from five to as high as $60 \%$ in some products.

Given respondents' socioeconomic characteristics, it is concluded that there is a potential market for organic vegetables in the study area. For instance, this survey revealed that among the surveyed consumers category of professional, those who work in NGOs and private companies were willing to pay more. The NGO workers did not mind to pay the doubled premium price from those who works in governmental organizations. Even when the price was higher, the consumers were willing to buy these products considering the lower risk related to their health.

Gender is an important variable related to premium prices. In Ethiopia, as in many other countries, women buy most foodstuffs for their households, while men tend to provide income, and women tend to manage household health issues. Some results from other studies are mixed. Some found no gender differences in WTP for healthy or organic fresh food. In contrast, others reported that women would pay more than men, e.g., for organic apples in the USA and Europe and for organic chicken meat in the USA. In Ethiopia, this survey found that $63 \%$ women (67\%) were willing to pay more than men (52\%).

The age variable also significantly corresponds to WTP. The research indicates that older consumers would pay more, a finding consistent with one study but not others who found that age was not a significant determinant of WTP for premium fresh foods. In this survey, the positive relationship between age and WTP for healthy fresh food could be because older people were more concerned about health. Consumers between 36 and 65 years of age showed a strong willingness to pay more for pesticide-free fruits and vegetables and/or IPM grown fruits and vegetables. Consumers under 36 years of age and over 65 years of age were not as willing as the older age groups to pay more.

Generally, this survey summarizes the findings of studies on consumers' awareness, perceptions, and their willingness to pay (WTP) premium for safety intervention. Various factors influence consumers' willingness to purchase. The following variables are significant and have a positive relationship with WTP. They are employment status, income, education. Income is the main factor that determines the purchasing power, consumption levels, and tastes of consumers. Higher income level leads to higher purchasing power, and vice versa. Consumer education can help us to get the best deals and avoid the worst pitfalls. If things do go wrong, consumer education can help us sort out our problems quickly and efficiently. An assertive, self-reliant consumer helps promote vigorous, competitive markets by demanding high standards from business.

\section{Research Implication}

The implication of this research focuses on the following issues. First, it is related to government support and policy. Considering the rising demand for organic products in the market, government's policy is required to enhance the consumers' attitude towards organic products as well as their purchase intention of organic food products, as in Taiwan (Chen, 2007). Furthermore, the government should have implemented a few strategies to ensure sustainable consumption and development in the country (Chen \& Chai, 2010). 
Second, it is on spreading knowledge and information. Advancement in technology and globalization has not only increased the choices of goods and services available to consumers but has also exposed consumers to some problems associated with rapid economic growth. There is an urgent need to educate consumers so that they are aware of their rights and avoid exploitation from unscrupulous manufacturers and sellers. There is a need to educate consumers about organic farming as well as organic food consumption and their respective benefits to human beings and the environment. With such knowledge and information provided, the consumers' perceptions and behavior may change, into being more concerned about health and the environment.

Third, it is about awareness building. The knowledge and awareness level among existing and new consumers on organic products can be an effective mechanism for the promotion of organic products in the future. Awareness can be increased through the campaign, demonstration, public gatherings, etc. The extension services, as well as government-led institutional supports in promoting organic farming, are very limited. Product certification is also not properly done by government agencies. Therefore, the government institutionally is required to develop the certification process as well as the branding of the products.

Fourth, it is the effort in enforcing consumer rights. In Ethiopia, almost half of the consumers in Addis Ababa do not know their rights, and falsehearted traders can easily exploit it. The consumer rights listed in the UN guidelines are the right to basic needs, the right to safety, the right to be informed, the right to choose, the right to education, the right to redress, and the right to a healthy environment. Consumers are required to encounter the available options to try to resolve the issue related to goods or services. The issues include boycotting the product/services, do nothing, switching brands or suppliers, warning friends and family, seeking redress directly from the retailer or manufacturer, or taking legal action, complaining to the media and/or registering a complaint with the consumer association. Consumers have a right to be protected by the consumer protection law, and institutions mandated to protect consumers. Consumer protection agencies have the mandate to stop anti-consumer trade practices such as contamination, substandard products, underweights, over-pricing, and misleading communications. Consumer protection organizations can explore innovative techniques, such as setting up websites, social media, and online blogs to disseminate appropriate information on consumer rights and redress mechanisms.

Fifth, it is about improving the learning curriculum. The government can review its national curricula to ensure consumer education is incorporated into the school learning curriculum starting at an early age and continuing through educational phases, as appropriate, to enable consumers to build knowledge in a cumulative fashion. This can be complemented by creating educational portals in which specific messages and videos are uploaded and made accessible to learners as well as to the general consumer audience.

Sixth, it is about the effort in developing promotion media. The media that can be used are both printed and digital media platforms, to publicize consumer-centered articles and news items on rights and redress measures. This can promote a much wider message, thus enhance consumer awareness given that mainstream media have, over the years, attained good national readership and viewership levels across the country. The media can help differentiate between the various 'pesticide safe' labels and the organic labels, spread information on organic labeling, or a premium price for organic food.

\section{CONCLUSION AND SUGGESTION}

Farmers applied extensive pesticides on vegetable farming in violation of the recommendations, like ignoring the risks and safety instructions, unsafe storage facilities, and did not use protective devices.

The majority of the consumers had known about organic food products. $62 \%$ of the respondents were moderately aware about the impact of non-organic nature of the food products. In comparison, $23 \%$ of the respondents were highly aware, and the remaining five percent of the respondents were not aware about the impact of non-organic products. Furthermore, $68 \%$ of 
consumers believed that the presence of pesticide residues was highly unsafe for health, and the remaining $32 \%$ of the respondents were not aware of it. The degree of consumers' awareness on their eight basic rights is low, with an average mean score of 3.16. The awareness about organic food is influenced by factors such as gender, age, education as well as income.

Increasing awareness about the benefits of organic vegetables compared to conventionallyproduced vegetables is relatively valuable. This survey shows that the tendency for organic vegetable consumption is moderate. $78 \%$ of consumers said that organic certification was essential. The majority (74\%) of the respondent showed the willingness to pay a premium (higher prices) for organic vegetables, and the remains, $24 \%$, were unwillingness to pay the premium. The premium price is ranging from $5-50 \%$ depending upon the products and consumers' willingness to buy. Consumers' willingness to purchase organic vegetables is influenced by employment status, income, education.

This research provides recommendations for increasing attention to organic products by focusing on government policy strategy to enhance the consumers' attitude, spreading knowledge and information, enforcing consumer rights, improving the learning curriculum, and developing promotion media. Future studies may consider the need for supporting organic product marketing and changes in consumers' behavior in response to expanding the use of information through social media.

\section{REFERENCES}

Aaker, D. A., \& Day, G. S. (1978). Consumerism: search for the consumer interest. Free Press. Retrieved

from https://books.google.co.id/books?id=rdtPAQAAI AA]

Al-Taie, W. A. A., Rahal, M. K. M., AL-Sudani, A. S. A., \& AL-Farsi, K. A. O. (2015). Exploring the Consumption of Organic Foods in the United Arab Emirates. SAGE Open, 5(2), 215824401559200. https://doi.org/10.1177/2158244015592001

Amoabeng, B. W., Gurr, G. M., Gitau, C. W., \& Stevenson, P. C. (2014). Cost benefit analysis of botanical insecticide use in cabbage:
Implications for smallholder farmers in developing countries. Crop Protection, 57, 7176.

https://doi.org/10.1016/j.cropro.2013.11.019

Amoah, P., Drechsel, P., Abaidoo, R. C., \& Ntow, W. J. (2006). Pesticide and Pathogen Contamination of Vegetables in Ghana's Urban Markets. Archives of Environmental Contamination and Toxicology, 50(1), 1-6. https://doi.org/10.1007/s00244-004-0054-8

Armah, F. A. (2011). Assessment of Pesticide Residues in Vegetables at the Farm Gate: Cabbage (Brassica oleracea) Cultivation in Cape Coast, Ghana. Research Journal of Environmental Toxicology, 5, 180-202. https://doi.org/10.3923/rjet.2011.180.202

Aryal, K., Chaudhary, P., Pandit, S., \& Sharma, G. (2009). Consumers' Willingness to Pay for Organic Products: A Case From Kathmandu Valley. Journal of Agriculture and Environment, 10(0). https://doi.org/10.3126/aej.v10i0.2126

Asadi, A., Akbari, M., Sharifzadeh, A., \& Hashemi, S. M. (2009). Analysis of Factors Affecting Agricultural Organic Products Diffusion Among Consumers: Perception of Extension Workers. World Applied Sciences Journal, 6(3), 331-338. Retrieved from http://www.idosi.org/wasj/wasj6(3)/5.pdf

Babin, B. J., \& Darden, W. R. (1995). Consumer self-regulation in a retail environment. Journal of Retailing, 71(1), 47-70. https://doi.org/https://doi.org/10.1016/00224359(95)90012-8

Batte, M. T., Hooker, N. H., Haab, T. C., \& Beaverson, J. (2007). Putting their money where their mouths are: Consumer willingness to pay for multi-ingredient, processed organic food products. Food Policy, 32(2), 145-159. https://doi.org/https://doi.org/10.1016/j.foodpo $\underline{1.2006 .05 .003}$

Bhatta, G. D., Doppler, W., \& Bahadur, K. K. (2009). Potentials of Organic Agriculture in Nepal. The Journal of Agriculture and Environment, 10, 1-11. Retrieved from https://www.nepjol.info/index.php/AEJ/article/vi $\underline{\mathrm{ew} / 2124 / 1956}$

Bhattarai, K. (2019). Consumers' willingness to pay for organic vegetables: Empirical evidence from Nepal. Economics and Sociology, 12(3), 132146. https://doi.org/10.14254/2071

Chen, M. F. (2007). Consumer attitudes and purchase intentions in relation to organic foods 
in Taiwan: Moderating effects of food-related personality traits. Food Quality and Preference, 18(7),

1008-1021. https://doi.org/10.1016/j.foodqual.2007.04.004

Chen, T. B., \& Chai, L. T. (2010). Attitude towards the Environment and Green Products: Consumers' Perspective. Management Science and Engineering, 4(2), 27-39. https://doi.org/10.3968/j.mse.1913035X201004 $\underline{02.002}$

Damte, T., \& Tabor, G. (2015). Small-scale vegetable producers' perception of pests and pesticide uses in East Shewa zone, Ethiopia. International Journal of Pest Management, 61(3), 212-219. https://doi.org/10.1080/09670874.2015.103682 2

Darko, G., \& Akoto, O. (2008). Dietary intake of organophosphorus pesticide residues through vegetables from Kumasi, Ghana. Food and Chemical Toxicology, 46(12), 3703-3706. https://doi.org/10.1016/j.fct.2008.09.049

de Bon, H., Huat, J., Parrot, L., Sinzogan, A., Martin, T., Malézieux, E., \& Vayssières, J.-F. (2014). Pesticide risks from fruit and vegetable pest management by small farmers in subSaharan Africa. A review. Agronomy for Sustainable Development, 34(4), 723-736. https://doi.org/10.1007/s13593-014-0216-7

De Groote, H., \& Kimenju, S. C. (2008). Comparing consumer preferences for color and nutritional quality in maize: Application of a semi-doublebound logistic model on urban consumers in Kenya. Food Policy, 33(4), 362-370. https://doi.org/10.1016/j.foodpol.2008.02.005

Dipeolu, A. O., Philip, B. B., Aiyelaagbe, I. O. O., Akinbode, S. O., \& Adedokun, T. A. (2009). Consumer awareness and willingness to pay for organic vegetables in S.W. Nigeria. (Special issue on organic farming and products.). Asian Journal of Food and Agro Industry, 2(Special Issue), S57-S65. Retrieved from https://unaab.edu.ng/consumer-awarenessand-willingness-to-pay-for-organic-vegetablesin-sw-nigeria/

Dumalagan, D. T. (2004). Economic Globalization and Its Impact on Consumer Rights: A Comparative Research and Analysis of Relevant Consumer Protection Laws and Programs in the Philippines, Thailand and Indonesia. Retrieved from

https://books.google.co.id/books?id=9r6wMQA ACAA]
Eom, Y. S. (1994). Pesticide Residue Risk and Food Safety Valuation: A Random Utility Approach. American Journal of Agricultural Economics, 76(4), 760-771. https://doi.org/10.2307/1243737

Gil, J. M., Gracia, A., \& Sánchez, M. (2000). Market segmentation and willingness to pay for organic products in Spain. The International Food and Agribusiness Management Review, 3(2), 207226. 7508(01)00040-4 https://doi.org/10.1016/S1096-

Gupta, N., \& Panchal, P. (2009). Extent of Awareness and Food Adulteration Detection in Selected Food Items Purchased by Home Makers. Pakistan Journal of Nutrition, 8, 660667. https://doi.org/10.3923/pjn.2009.660.667

Harland, D. (1990). Implementing the Principles of the United Nations Guidelines for Consumer Protection. In Seminar on Consumer Protection for Asia and the Pacific,. Bangkok, June 19-22, 1990: UNITED NATIONS CONFERENCE ON TRADE AND DEVELOPMENT. Retrieved from https://unctad.org/en/PublicationsLibrary/ditccpl pmisc2016d1 en.pdf

Hough, P. (2003). Poisons in the System: The Global Regulation of Hazardous Pesticides. Global Environmental Politics, 3(2), 11-24. https://doi.org/10.1162/152638003322068182

Ibarra, V. C. (2014). Consumers' Awareness on Their Eight Basic Rights: A Comparative Study of Filipinos in The Philippines And Guam. International Journal of Management and Marketing Research, 7(2), 1933-3153. Retrieved from ftp://ftp.repec.org/opt/ReDIF/RePEc/ibf/ijmmre/ ijmmr-v7n2-2014/IJMMR-V7N2-2014-6.pdf

Ishak, S., \& Zabil, N. F. M. (2012). Impact of consumer awareness and knowledge to consumer effective behavior. Asian Social Science, 8(13), 108-114. https://doi.orq/10.5539/ass.v8n13p108

Jansen, H. C., \& Harmsen, J. (2009). Pesticide Monitoring in the Ecosystems for Water in Ethiopia. Wageningen. Retrieved from http://library.wur.nl/WebQuery/wurpubs/fulltext $\angle 173773$

Katrin, H., Gårn, L., Millock, K., Hansen, L. G., Wier, M., \& Andersen, L. M. (2013). Willingness to Pay for Organic Foods: A Comparison between Survey Data and Panel Data from Denmark (Vol. 47588). Retrieved from https://mpra.ub.unimuenchen.de/47588/1/MPRA paper 47588.pdf 
Loureiro, M. L., Mccluskey, J. J., \& Mittelhammer, R. O. N. C. (2002). Will Consumers Pay a Premium for Eco-labeled Apples? Journal of Consumer Affairs, 36(2), 203-219. https://doi.org/10.1111/j.17456606.2002.tb00430.x

Lund, T., Sthre, M. G., Nyborg, I., Coulibaly, O., \& Rahman, M. H. (2010). Farmer field school-IPM impacts on urban and peri-urban vegetable producers in Cotonou, Benin. International Journal of Tropical Insect Science, 30(1), 1931.

\section{https://doi.org/10.1017/S1742758410000020}

Martin, T., Assogba-Komlan, F., Houndete, T., Hougard, J. M., \& Chandre, F. (2009). Efficacy of Mosquito Netting for Sustainable Small Holders' Cabbage Production in Africa. Journal of Economic Entomology, 99(2), 450-454. https://doi.org/10.1603/0022-0493-99.2.450

Mason, R. B. (2007). Consumer Protection Awareness in South Africa. World Journal of Retail Business Management, 1(1), 2735. Retrieved from https://wlv.openrepository.com/handle/2436/18 697

Mengistie, B. T., Mol, A. P. J., \& Oosterveer, P. (2016). Private Environmental Governance in the Ethiopian Pesticide Supply Chain: Importation, Distribution and Use. NJAS Wageningen Journal of Life Sciences, 76, 6573. https://doi.org/10.1016/j.njas.2015.11.005

Mengistie, B. T., Mol, A. P. J., \& Oosterveer, P. (2017a). Governance of agro-pesticide through private environmental and social standards in the global cut flower chain from Ethiopia. Ambio, 46(7), 797-811. https://doi.org/10.1007/s13280-017-0914-x

Mengistie, B. T., Mol, A. P. J., \& Oosterveer, P. (2017b). Pesticide use practices among smallholder vegetable farmers in Ethiopian Central Rift Valley. Environment, Development and Sustainability, 19(1), 301-324. https://doi.org/10.1007/s10668-015-9728-9

Mengistie, B. T., Mol, A. P. J., Oosterveer, P., \& Simane, B. (2015). Information, motivation and resources: the missing elements in agricultural pesticide policy implementation in Ethiopia. International Journal of Agricultural Sustainability, 13(3), 240-256. https://doi.org/10.1080/14735903.2014.959330

Menon, M. (2008). Organic Agriculture and Market Potential for Organic products in India. In P. Chaudhary, K. Aryal, \& D. Tharu (Eds.),
International Workshop on Opportunities and Challenges of Organic Production and Marketing in South Asi (pp. 87-94). Kathmandu, Nepal.

Muhammad, S., Fathelrahman, E., \& Ullah, R. U. T. (2017). The Significance of Consumer's Awareness about Organic Food Products in the United Arab Emirates. Sustainability, 9(2), 1-1. https://doi.org/10.3390/su9020326

Negatu, B., Kromhout, H., Mekonnen, Y., \& Vermeulen, R. (2016). Use of Chemical Pesticides in Ethiopia: A Cross-Sectional Comparative Study on Knowledge, Attitude and Practice of Farmers and Farm Workers in Three Farming Systems. The Annals of Occupational Hygiene, 60(5), 551-566. https://doi.org/10.1093/annhyg/mew004

Ntow, W. J., Gijzen, H. J., Kelderman, P., \& Drechsel, P. (2006). Farmer perceptions and pesticide use practices in vegetable production in Ghana. Pest Management Science, 62(4), 356-365. https://doi.org/10.1002/ps.1178

Peter, J. P., \& Olson, J. C. (2010). Consumer Behavior and Marketing Strategy (9th ed.). McGraw-Hill Irwin. Retrieved from https://books.google.co.id/books?id=4D1VPgAA CAA]

Pimentel, D. (1995). Amounts of pesticides reaching target pests: Environmental impacts and ethics. Journal of Agricultural and Environmental Ethics, 8(1), 17-29. https://doi.org/10.1007/BF02286399

Singh, B. (2002). Consumer Education on Consumer Rights and Responsibilities, Code of Conduct for Ethical Business and Importance of Product Labelling. Petaling Jaya, Kuala Lumpur: Ministry of Domestic Trade and Consumer Affairs (MDTCA) Federation of Malaysian Consumers Associations (FOMCA) Education and Research Association for Consumers (ERA Consumer Malaysia) Muslim Consumers Association of Malaysia (PPIM). Retrieved from https://dsam.org.my/consumer-education/913

Timbilla, J. A., \& Nyarko, K. O. (2004). A survey of cabbage production and constraints in Ghana. Ghana Journal of Agricultural Science, 37(1), 93-101. Retrieved from http://www.ajol.info/index.php/gias/article/view 2084/10915

Van Loo, E. J., Caputo, V., Nayga, R. M., Meullenet, J.-F., \& Ricke, S. C. (2011). Consumers willingness to pay for organic chicken breast: Evidence from choice experiment. Food Quality 
and Preference, 22(7), 603-613. https://doi.org/10.1016/j.foodqual.2011.02.003

Vanit-Anunchai, C., \& Schmidt, E. (2004). Consumer willingness to pay for environmentally friendly produced vegetables in Thailand. In Acta Horticulturae (Vol. 655, pp. 107-113). International Society for Horticultural Science.

https://doi.org/10.17660/ActaHortic.2004.655.1 $\underline{3}$

Williamson, S. (2012). Breaking the barriers to IPM in Africa: Evidence from Benin, Ethiopia, Ghana and Senegal. In Pretty, J N. In J. Pretty (Ed.), The Pesticide Detox: Towards a More Sustainable Agriculture (pp. 165-180). London, UK: Earthscan. Retrieved from
https://books.google.co.id/books?id=uMBpYzCP uUAC

Wilson, B. B. (2008). Get to Know Your Basic Consumer Rights: How Do They Work for You? Alabama: Alabama Cooperative Extension System (Alabama A\&M and Auburn Universities) in cooperation with the U.S. Department of Agriculture. Retrieved from https://ssl.acesag.auburn.edu/pubs/docs/U/UNP -0040/UNP-0040-archive.pdf

Zander, K., \& Hamm, U. (2010). Consumer preferences for additional ethical attributes of organic food. Food Quality and Preference, 21(5),

495-503. https://doi.orq/10.1016/j.foodqual.2010.01.006 


\section{Appendix. Conceptualizing the eight basic rights of consumers}

Consumer rights are now an integral part of consumers' life. The review of literature presented below is limited to the eight basic consumer rights as defined by (Ibarra, 2014). Consumer awareness is referred to as the perception or understanding of these rights by consumers.

(i) The first right refers to basic needs. This right ensures the availability of basic goods and services to consumers at affordable prices and of good quality. It includes adequate food, clothing, shelter, health care, education, public utilities, water, and sanitation to lead a decent life. Based on these human needs, the United Nations Guidelines on Consumer Protection defines sustainable consumption as including "meeting the needs of present and future generations for goods and services in ways that are economically, socially and environmentally sustainable". The Universal Declaration of Human Rights in 1948, Paris (Article 25), as cited by United Nations Educational Scientific and Cultural Organization (UNESCO) further signifies that "Everyone has the right to a standard of living adequate for the health and well-being of himself and of his family, including food, clothing, housing and medical care and necessary social services.

(ii) The second right pertains to safety. This right assures consumers to be protected against the marketing of goods which are injurious to health and life. Consumers are assured that manufacturers of consumer products undertake extensive safety and performance testing before selling their products in the market. Products should be properly labeled with information as to the contents, use, precautions or warning signs and how to prepare it, if the need arises. (Wilson, 2008) argues that consumers have the right not only to expect protection from hazardous products and services purchased in the marketplace, particularly if used properly for their intended purpose but also the right to be protected from the sale and distribution of dangerous goods and services. On the other hand, (Dumalagan, 2004) emphasizes that all consumers are entitled to safety against the marketing of goods or the provision of services that are hazardous to their health and life. She supports that economic globalization may benefit the consumers as a consequence of the expanding circulation of goods and services, thus, enhancing their right of choice, based on needs and purchasing power. Conversely, it may also create certain uncertainty about their safety. As (Harland, 1990) declares, the capacity of goods and services to cause serious injury or death has vastly increased as consumers are often faced with inadequate information to assess whether these goods and services conform to basic safety requirements.

(iii) The third is the right to information. This is the right of consumers to be protected against dishonest or misleading advertising or labeling and the right to be given the facts and information needed to make an informed choice. Consumers have the right to receive adequate information about products on which to base buying decisions. Information to consumers includes product specification, place of origin, safety warnings, price, mode of payment, date of quality assurance, description of after-sale services, warranty, ingredient, nutritional facts, etc. Consumers expect complete information about the product to be purchased, including its use, ingredients or chemical contents, limitations, and expiry date. Consumers must be informed about the safety precautions to be taken while using the product to avoid loss or injury. Limited information is one of the factors causing the exploitation of consumers. (Aaker \& Day, 1978) cited the right to be informed as a fundamental economic interest of the consumer. They believe that consumers should be provided with sufficient information to make wise purchase decisions. Information should not be persuasive, as shown by commercials but should be informative. At present, products are massive in quantity and more complicated to assess. Against these numerous products are lay buyers who do not have the time or the capacity to obtain information to help them in making the correct decision to buy. Along this line, (Peter \& Olson, 2010) demonstrated that a substantial amount of marketing information is miscomprehended in that consumers form inaccurate, confused, or inappropriate information interpretation. The type of miscomprehension can vary from confusion over similar brand names to misinterpreting a product claim by forming an inaccurate means-end chain.

(iv) The fourth is the right to choose. This deals with the right to choose products and services at competitive prices, with an assurance of satisfactory quality. Consumers expect a wide array of goods and services which are offered in the market with diverse brands, sizes, shapes, colors, and differences in the price, quality, and use. Consumers have the right to be assured that a selection of quality products and services are available for them to purchase at competitive prices. The right to choose also intends to protect competitors from each other, particularly the small firms from large and powerful ones. According to (Wilson, 2008), a consumer should have the opportunity to select the goods or services that he or she wants to purchase. (Gupta \& Panchal, 2009) pointed out that with the rise in the income of people, the quality, quantity, and sophistication of the consumer goods has also increased. They believe that the market literally overflows with new products based on intricate technology, thus making it very difficult for the consumer to select an item because of misleading advertisements and improper media emphasis as well.

(v) The fifth right refers to representation. The right to representation is also known as the right to be heard. This is the right to express consumer interest in the making and execution of government policies that will have an impact on the supply of goods and services to consumers. Consumers expect legislators would propose laws that would ensure that consumers would have the chance to live a better life by getting the best value for their hardearned money. Consumers have the right to equal and fair consideration in government policy-making situations, as well as prompt treatment in administrative courts or legal communities. Consumers have the right to complain when there are problems or concerns. The right to be heard involved an assurance that consumers would be considered in the formulation of government policy and during regulatory proceedings. Some business enterprises advocate this consumer right in formulating their policies (Aaker \& Day, 1978). 
(vi) The sixth is the right to redress. This is the right of consumers to be compensated for misrepresentation, shoddy goods or unsatisfactory services. Under this right, consumers expect defective goods to be replaced or money refunded by the seller or dealer. Consumers also have the right to seek legal remedies in the appropriate courts of law. Through this right, the consumers are assured that their complaints will receive due attention. This right also provides for due compensation to consumers if they have suffered a loss or are put to jeopardy due to the fault of the supplier or manufacturer. (Aaker \& Day, 1978) pointed out that consumers should be given an opportunity to voice dissatisfaction and complaint is settled satisfactorily. A variety of innovations, including free legal service for the poor, consumer class action suits, and arbitration procedures have substantially enhanced the right to recourse and redress, or to fair settlement of just claims.

(vii) The seventh right pertains to consumer education. This is the right to acquire the knowledge and skills necessary to be an informed consumer. Consumers may look forward to the three sectors of society: business, government, and the consumer would embark on an information campaign through tri-media on consumer-related issues as well as series of seminars, conferences, for training and public hearings for the welfare of the consumer. To prevent market malpractices and exploitation of consumers, consumer awareness and education are essentially required. Recognizing the importance of consumer education, (Singh, 2002) lays down four important aspects: (a) Informed Choice- Consumers must learn to obtain information on goods and services, discriminate between sources of information, understand the psychology of selling and advertising; (b) Value Systems- Consumer education must enable the consumer to understand that individual consumer decision have a broad social impact and influence on such important things as the overall allocation of resources within the society; (c) Wise Decision Making- Consumers need the information to make careful, wise decisions and informed choices; and, (d) Catalyst for Action- Consumers must be aware of the available avenues of consumer complaint and redress and learn to use them for their benefit.

(viii) Lastly, the eight rights concern a healthy environment. This right assures consumers to live and work in an environment that is neither threatening nor dangerous and which permits a life of dignity and wellbeing. Consumers expect the government exerting effort regarding the alarming increase in the degradation of the environment especially on forest, dying wildlife, depleted landfill space and environmental contamination to preventing further damage and the constant monitoring of our seas, coral reefs, forest and waste disposal being committed by factories to check if there is a violation of the laws on environmental protection. (Dumalagan, 2004) emphasizes that all consumers are entitled to a healthy environment and should be protected from the devastating effects of air, earth, and water pollution that may affect the performance of daily marketplace operations. Consumers have the right to live and work in an environment that does not threaten the well-being of present and future generations. 